\title{
The Influence of Hedonic Motives on Online Impulse Buying through Shopping Lifestyle for Career Women
}

\author{
Wilma Laura Sahetapy ${ }^{1 *}$, Eufemia Yunnni Kurnia ${ }^{1}$, and Olga Anne ${ }^{2}$ \\ ${ }^{1}$ Department Management, Faculty of Business and Economics, Petra Christian University, \\ Jl. Siwalankerto 121-131, Surabaya 60236, Indonesia \\ ${ }^{2}$ Department of Natural Sciences, Faculty of Marine Technology and Natural Sciences of Klaipeda \\ University, H. Manto g. 84, Klaipeda 92294, Lithuania
}

\begin{abstract}
This research aims to know the influence of hedonic motives on impulse buying, shopping lifestyle on impulse buying, and hedonic motives on shopping lifestyle. The data are collected from questionnaires distributed to 130 respondents. The respondents are obtained from judgmental sampling or non-random sampling. The data are processed with SmartPLS software as the analytical tool. The results of this research show that hedonic motives and shopping lifestyle have a significant influence on impulse buying.
\end{abstract}

Keywords: E-commerce, Impulsive purchases, internet purchase, shopping activities, shopping motivation

\section{Introduction}

Life demands in the modern era are increasing with increasing competition in various economic sectors. This makes the cost of living borne by a household cannot be relied solely on men's income as head of the household. The report published by the ILO (International Labor Organization) explained that there was a significant increase in the number of career women (working women), where employment profiles by sex showed the percentage of women working as professionals/technicians in 2016 an increase of $10.3 \%$ [1]. An increase in the number of career women will automatically increase the income received by the woman herself. This makes women more flexible in making decisions, especially related to shopping activities. Fernandes and Londhe [2] say that compared to ordinary housewives, career women play a more important role in shopping activities, which is $95 \%$. In this case, women who shop more often are career women.

In this research shopping activities will be focused in the form of online shopping activities. Online shopping, also known as internet shopping, electronic shopping, online purchases or internet purchases. To and Sung [3] explain that there is currently a rapid increase in online shopping activities. The population in Indonesia in 2012 reached $244 \times 10^{6}$ with the number of consumers who shop online around $13 \times 10^{6}$. In 2013 , the population in Indonesia reached $247 \times 10^{6}$ people with the number of consumers who shop online reached $20 \times 10^{6}$ people, greater than in 2012. In 2012, e-commerce companies in

*Corresponding author: wilma@petra.ac.id 
Indonesia noted that $41 \%$ of their sales came from Jakarta. Data from the IDC research institute (Indonesia Data Center) predicts that the e-commerce market in Indonesia grows $42 \%$ from 2012 to 2015 [4].

Data explained that the data of the Surabaya City Population and Civil Registry Office stated that in 2017 the population of Surabaya city was 3057766 people [5]. They consisted of 1526583 men and 1531183 women. The number of women who are more in accordance with the focus of research that is the women's fashion market. In addition, in the city of Surabaya there are 32 shopping centers, which by 2020 will add 13 more shopping centers. The data described above shows how much the potential of women, especially career women because they already have their own income derived from the work they have, as a market share of online fashion products.

Hedonic Motives is something that can encourage a person to fulfill his desires for pleasure and material enjoyment as his main focus [6]. Hedonic Motives as a motive underlying shopping behavior can affect many things, one of which is shopping lifestyle. The many needs for primary and secondary goods make consumers always want to meet their needs and desires, this is what underlies the shopping lifestyle. Shopping lifestyle refers to consumption patterns that reflect a person about how to spend time and money to shop.

In this research, impulse buying activities are described by sudden and unplanned purchases made through the E-commerce website. Because online shoppers play a dual role, namely as traditional buyers and at the same time as internet users, the motivation and dimensions of impulse buying flow come from the existing online shopping environment [3].

Shopping activities are carried out by everyone, both men and women, but research shows that shopping culture is mostly done by women, this is proven by Women Certified revealed that $83 \%$ of consumers who shop at the end the 20th century are women. Women shop not only because they need something, but for women shopping is a recreational activity that allows them to try on all kinds of clothes and shoes [7]. Meanwhile, it is also known from the results of a preliminary survey that women generally have a shopping lifestyle and there is a tendency to impulse buying when shopping. Comparisons between career women and those who have not worked in terms of hedonic motives, shopping lifestyle, and impulse buying are generally proportional. However, in this study the researchers chose to use career women as research objects because their financial resources are more independent so that shopping decisions made will be more influenced by themselves than those who have not worked.

Based on the description of various previous studies, then in this study will be further observed about the "Effect of Hedonic Motives on Impulse Buying online through Shopping Lifestyle on career women in Surabaya.

\section{Literature Review}

\subsection{Career}

Career advancement is usually understood as promotion in the management ranks and achieving higher levels of management and salary [8]. Women work in the background not only because of economic reasons, but also the existence of knowledge and selfactualization skills and want to gain inner satisfaction, which is caused by the general perception that the world of work is the world of men [9]. 


\subsection{E-Commerce}

E-commerce is business activities involving consumers, manufactures, service providers and intermediary traders using computer networks, namely the internet. It can be concluded that the meaning of e-commerce is all forms of trade transactions / trade in goods or services (trade of goods and service) using electronic media [10]. Online shopping is defined as the activity of checking, searching, searching or viewing products to get more information that triggers the possibility of purchase intention on the internet [11]. In an online shopping environment, consumers are free to shop on various websites and consumers can switch from one website to another with just one click.

\subsection{Shopping motivation}

Online shopping behavior refers to the process of purchasing products or services via the internet. There are more reasons or needs why an individual can decide to go shopping [12]. This reason or need is called shopping motivation. Hedonic shopping motivation is a form of attitude that arises spontaneously from within the consumer [13]. There are several categories of hedonic shopping including adventure shopping, namely shopping for a trip, carried out for adventure and feel a different world, and gratification shopping that is shopping done with the aim of relieving stress, reducing boredom, and to please yourself. Shopping lifestyle is a lifestyle that refers to how a person lives, how they spend time, money, purchasing activities carried out, their attitudes and opinions about the world where they live [14]. Stating that the factors that influence a person's lifestyle there are two factors, namely factors originating from within the individual (internal) and factors originating from the outside (external). Shopping lifestyle is an expression of lifestyle in shopping that reflects differences in social status [15].

\subsection{Impulse Buying}

Impulsive purchases of goods occur when consumers feel the experience, sometimes the strong desire, to buy goods suddenly without any prior plan [14]. The impulse buying is defined as an act of buying that was not previously consciously recognized as a result of a consideration or purchase intention that was formed before entering the store [15].

\subsection{Relationships among concepts}

\subsubsection{The hedonic motives and the shopping lifestyle}

Hedonic motives had a significant and positive effect on shopping lifestyle [15]. Hedonic motives are created with a shopping passion that always enjoys time when shopping which will affect shopping lifestyle because the hedonic nature of someone makes them forget or no longer think about the benefits or benefits of the products consumers buy. Based on the results of various previous studies, the hypotheses compiled in this study related to the relationship between hedonic motives and shopping lifestyle are:

$\mathrm{H}_{1}$ : Hedonic motives influences positively and significantly on shopping lifestyle

\subsection{The shopping lifestyle and the impulse buying}

Shopping lifestyle has a significant positive effect on impulse buying [6]. Shopping habits (shopping lifestyle) is motivated by a lifestyle that likes to spend money and time to shop [15]. This is what triggers impulse buying. Based on the results of various previous studies, 
the hypotheses compiled in this study related to the relationship between shopping lifestyle and impulse buying are:

$\mathrm{H}_{2}$ : Shopping lifestyle influences positively and significantly on impulse buying

\subsection{The hedonic motives and the impulse buying}

Hedonic motives had a significant and positive effect on impulse buying [15]. When shopping someone sometimes makes unplanned purchases or purchases that are not on their shopping list. The sense of excitement that arises from consumers who shop hedon, raises a buying behavior of goods that are substantially not really needed by consumers. Based on the results of various previous studies, the hypotheses compiled in this study related to the relationship between hedonic motives and impulse buying are:

$\mathrm{H}_{3}$ : Hedonic motives influences positively and significantly on impulse buying

\section{Results}

The number of respondents in this study were 130 career women respondents who shop online. Based on the table above it can be seen that the career female respondents used in this study are aged in the range of $24 \mathrm{yr}$ to $30 \mathrm{yr}$, as many as 76 respondents and represent the percentage of $58.46 \%$.

The result shows that the majority of career female respondents have a background of employment as private workers, as many as 98 people with a percentage level of $75.38 \%$, while the remaining 32 people have occupational backgrounds as entrepreneurs. This shows that the profession of career women in this study is primarily as private workers and not entrepreneurs because most career women who have a high enough level of education tend to try to get an achievement for a job and also additional experience at work.

\subsection{The influence of hedonic motives on shopping lifestyle}

The results obtained in this study indicate that hedonic motives have a significant positive effect on shopping lifestyle, which means that the greater the hedonic motives that are owned, the more influence on one's shopping lifestyle [6, 15].

From the results of the cross tabulation analysis also obtained information that in this study career women aged $24 \mathrm{yr}$ to $30 \mathrm{yr}$ spent IDR $1 \times 10^{6}$ to $3 \times 10^{6} \mathrm{mon}^{-1}$ as many as 21 people and aged $17 \mathrm{yr}$ to $23 \mathrm{yr}$ as many as 30 people with a majority of three to five times the frequency of shopping and products which is most often bought belongs to the category of fashion products. These results indicate that in this study there are true hedonic motives which are indicated by the magnitude of spending figures and the frequency of purchases. In addition, research shows that women generally like fashion products and want to own products that are rarely owned by others. This is confirmed from the results of a descriptive analysis of the shopping lifestyle variable which shows the highest mean value is the indicator with the statement "I feel by choosing a place or shop in online shopping can affect my social status". This is what causes hedonic motives to positively influence shopping lifestyle.

\subsection{The influence of Shopping Lifestyle on Impulse Buying}

The results obtained in this study indicate that shopping lifestyle has a significant positive effect on impulse buying which means that shopping lifestyle of a person will increase the tendency of impulse buying behavior $[6,14]$. If observed from the demographic profile of 
the respondents, it can be seen that the majority of respondents are in the age range of $24 \mathrm{yr}$ to $30 \mathrm{yr}$ and in the second place is at the age of $17 \mathrm{yr} 23 \mathrm{yr}$. From the results of the cross tabulation analysis also obtained information that in this study career women also have a certain shopping pattern that is three to five times a month. This shows the existence of shopping lifestyle. From the results of descriptive analysis found for the variable impulse buying, the highest mean is the indicator with the statement "There is a desire or encouragement from within yourself when making purchases online". The desire or urge to buy can be influenced by products sold online. Fashion and food and beverages are the product categories that are most in demand by respondents in this study. The product categories of interest are the types of products that are very easy to attract attention to do impulse buying. This has caused shopping lifestyle to have a significant positive effect on impulse buying in this study.

\subsection{The influence of hedonic motives on impulse buying}

The results obtained in this study indicate that hedonic motives have a significant positive effect on impulse buying, which means that shopping lifestyle of a person will increase the tendency of impulse buying behavior $[6,14,15]$. In this study used career women as research objects. Women who work will be more flexible in managing expenses because they have their own source of income. The demographic profile in this study is dominated by career women in the age range of $24 \mathrm{yr}$ to $30 \mathrm{yr}$, with a background in private employee employment, single and over $5 \mathrm{yr}$ of work. This is what causes if the respondent has a hedonic motive then it will be easier to do impulse buying.

\section{Discussion}

The hedonic motives variable has a significant influence on shopping lifestyle because the T-statistic value is 3.922 which means it is greater than the T-count of 1.96. Thus, the H1 hypothesis which reads "Hedonic motives has a significant positive effect on shopping lifestyle" can be accepted. The higher the hedonic motives experienced by consumers when shopping, the shopping lifestyle increases when shopping online. Second, The shopping lifestyle variable has a significant effect on impulse buying because the T-statistic value is 3.87 which means it is greater than the T-count of 1.96 . Thus, the $\mathrm{H} 2$ hypothesis which says "shopping lifestyle has a significant positive effect on impulse buying" can be accepted. The higher shopping lifestyle experienced by consumers when shopping online increases impulse buying in conducting online shopping transactions. Third, the hedonic motives variable has a significant influence on impulse buying, because the T-statistic value is 17.549 which means it is greater than the T-count of 1.96. Thus, the H3 hypothesis which reads "Hedonic motives has a significant positive effect on impulse buying" can be accepted. The higher the hedonic motives experienced by consumers when shopping online, it increases the impulse buying of these consumers.

\section{Conclusion}

Based on the results of the data analysis and discussion, it can be drawn several conclusions; i), hedonic motives have a significant positive effect on shopping lifestyle which is caused by the high hedonic motives of the residents of Surabaya and is supported by high incomes so that enable the citizens to increase their shopping lifestyle. ii) Shopping lifestyle of the residents of Surabaya can increase the numbers of impulse buying which is 
offered by various providers, besides, the income of career women is relatively higher than the standard salary. iii.) Hedonic motives have a significant positive effect on impulse buying. Indirect effect between hedonic motives and impulse buying through shopping lifestyle shows a significant effect. It means shopping lifestyle acts as the intervening variable which strengthens the effect of hedonic motives to impulse buying.

\section{References}

1. W. Abdillah, H.M. Jogiyanto, Konsep dan Aplikasi PLS (Partial Least Square) Untuk Penelitian Empiris. [Concept and Application of PLS (Partial Least Square) for Empirical Research]. Yogyakarta: Badan Penerbit Fakultas Ekonomi (2009). [in Bahasa Indonesia]. https://scholar.google.com/scholar?cluster=12451235871909502149

2. S. Fernandes, B.R. Londhe, Indian Journal of Commerce \& Management Studies, 5,2:91-98(2014). https://pdfs.semanticscholar.org/ec03/5e503d7a96a1fe157ef428216cccd9a885c6.pdf

3. P.L. To, E.P. Sung, International Journal of Economics and Management Engineering, 8,7:2230-2232(2014). https://pdfs.semanticscholar.org/1d1f/c48befe14164db4aae28b8b842f5930756bc.pdf

4. P.D.P. Dewi, E-Proceeding of Management, 2,2:1321-1326(2015). [in Bahasa Indonesia]. http://jurnalpemasaran.petra.ac.id/index.php/mar/article/view/19185

5. A.D. Hapsari, M. Iqbal, Jurnal Administrasi Bisnis, 64,2:27-35(2018). [in Bahasa Indonesia]. http://administrasibisnis.studentjournal.ub.ac.id/index.php/jab/article/view/2752

6. M. Andryansyah, Z. Arifin, Jurnal Administrasi Bisnis, 57,1:111-118(2018). [in Bahasa Indonesia]. http://administrasibisnis.studentjournal.ub.ac.id/index.php/jab/article/view/2358

7. I. Rufaida, D.Y. Setiyarini, S. Prasetyaningtyas, Motif Belanja Konsumen Wanita Di Pusat Perbelanjaan Roxy Square Jember [Women's Shopping Motives At Roxy Square Shopping Center Jember]. [Student research], Universitas Jember, Indonesia, 2016. [in Bahasa Indonesia]. http://repository.unej.ac.id/handle/123456789/73711

8. L. Yet-Mee, T.L. Peng, B.C. Yin-Fah, Journal of Human and Social Science Research, 2,1:21-34(2013). https://www.academia.edu/download/48455830/A_Study_on_Womens_Career_Adva ncement_in20160830-21496-ssys14.pdf

9. Iklima. eJournal Sosiaatri Integratif, 2,3:77-89(2014). [in Bahasa Indonesia]. https://ejournal.sos.fisip-unmul.ac.id/site/?p=657

10. D. Ardyanto, H. Susilo, Riyadi. Jurnal Administrasi Bisnis, 22,1:1-8(2015). [in Bahasa Indonesia]. http://administrasibisnis.studentjournal.ub.ac.id/index.php/jab/article/view/882

11. N. Ahmad, A. Omar, T. Ramayah, Business Strategy Series, 11,4:227-243(2010). https://www.emerald.com/insight/content/doi/10.1108/17515631011063767/full/html

12. C. Topaloglu, Asian Academy of Management Journal, 17,2:1-19(2012). http://eprints.usm.my/36578/1/AAMJ 17.2.1.pdf

13. R.R. Ridha, F.S.A. Prabowo, E-Proceeding of Management, 2,3:2878-2883(2015). [in Bahasa indonesia]. https://202.134.6.251/index.php/management/article/view/948

14. A. Kosyu, K. Hidayat, Y. Abdillah, Jurnal Administrasi Bisnis, 14,2:1-7(2014). [in Bahasa Indonesia]. https://media.neliti.com/media/publications/84440-ID-pengaruhhedonic-shopping-motives-terhad.pdf 
15. F.Y. Setyningrum, Z. Arifin, E. Yulianto, Jurnal Administrasi Bisnis, 37,1:97104(2016). [in Bahasa Indonesia].

http://administrasibisnis.studentjournal.ub.ac.id/index.php/jab/article/view/1432

16. L.A. Darma, E. Japarianto, Jurnal Manajemen Pemasaran, 8,2:80-89(2014). [in Bahasa Indonesia].

http://jurnalpemasaran.petra.ac.id/index.php/mar/article/view/19185 